Research article

2021 | Volume 9 | Issue 2 | Pages 24-30

ARTICLE INFO

Received

January 21, 2021

Revised

March 25, 2021

Accepted

March 28, 2021

Published

May 02, 2021

*Corresponding authors

Baseer Ahmad

E-mail

dr.baseerahmadkhan@gmail.com

Keywords

Fibrinolytic enzyme

Metal ions

Optimization

Streptokinase

Streptococcus equisimilis

How to cite

Tanveer R, Gulzar H, Ahmad

B, Akhtar M, Hussain I, Hanif

Q, Khan M, Khan RU.

Optimization of metal ions in sugarcane bagasse fermenting medium for the production of

streptokinase by

Streptococcus equisimilis. Sci

Lett 2021; 9(2):24-30

\#Note

These authors contributed equally
Open Access

\section{Optimization of Metal lons in Sugarcane Bagasse Fermenting Medium for the Production of Streptokinase Streptococcus equisimilis}

Rida Tanveer ${ }^{1 \#, ~ H u m a ~ G u l z a r 1, ~ 2 \#, ~ B a s e e r ~ A h m a d ³, 4 *, ~ M a r y a m ~}$ Akhtar $^{5}$, Iqra Hussain ${ }^{1}$, Quratulain Hanif ${ }^{6}$, Mirwaise Khan ${ }^{3}$, Rahat Ullah Khan ${ }^{7}$

${ }^{1}$ Department of Biochemistry and Biotechnology, The Islamia University, Bahawalpur 63100, Pakistan

${ }^{2}$ College of Life Sciences, China Agriculture University, Beijing, China

${ }^{3}$ Faculty of Veterinary and Animal Sciences, Gomal University, D. I. Khan, Pakistan

${ }^{4}$ College of Animal Science and Technology, China Agriculture University, Beijing, China

${ }^{5}$ College of Life Sciences, Lanzhou University, China

${ }^{6}$ Computational Biology Laboratory, Agricultural Biotechnology Division, National Institute for Biotechnology and Genetic Engineering, Faisalabad, Pakistan

${ }^{7}$ Institute of Microbiology, Gomal University, Dera Ismail Khan, Khyber Pakhtunkhwa, Pakistan

\section{Abstract}

Streptokinase is a fibrinolytic enzyme and a product of $\beta$-hemolytic Streptococci strains. This enzyme is used as a medication to break down clots in some cases of heart disease. Streptococcus equisimilis, a species of group C Streptococci, is widely used for the production of streptokinase by fermentation technology. In this study, the sugarcane bagasse fermentation medium was optimized for metal ions $\left(\mathrm{KH}_{2} \mathrm{PO}_{4}, \mathrm{MgSO}_{4} .7 \mathrm{H}_{2} \mathrm{O}, \mathrm{CaCO}_{3}\right.$ and $\mathrm{NaHCO}_{3}$ ) at various levels to attain the maximal production of streptokinase. Sugarcane bagasse was used due to its profuse availability and as an ideal substrate for microbial processes for the manufacturing of value-added products. The results showed that maximal streptokinase production was found at $0.04 \% \mathrm{KH}_{2} \mathrm{PO}_{4}, 0.04 \% \mathrm{MgSO}_{4} .7 \mathrm{H}_{2} \mathrm{O}, 0.15 \% \mathrm{NaHCO}_{3}$ and $0.04 \%$ $\mathrm{CaCO}_{3}$. Finally, the optimized medium resulted in $84.75 \mathrm{U} / \mathrm{mg}$ specific activity and $74.5 \%$ recovery. The purification process was carried out simultaneously using ammonium sulfate precipitation, ion-exchange chromatography, and gel filtration. Finally, a purified sample of streptokinase was run on SDS-PAGE and resolute $47 \mathrm{kDa}$ molecular weight. The use of $\beta$ hemolytic Streptococci to obtain streptokinase is not free from health risks and is related to anaphylaxis. This study provides a way forward for the costeffective ways to obtain streptokinase for the treatment of thrombosis.

This work is licensed under the Creative Commons Attribution-NonCommercial 4.0 International License. 


\section{Introduction}

Cardiovascular diseases have become a leading cause of death worldwide. An acute coronary syndrome is a term, accepted for the reason that it was thought to be more noticeably revealing the disease development which is related to myocardial ischemia [1]. A vast variety of blood dissolving agents, including streptokinase, have been used for the cure of cardiac diseases. Due to pathogenesis such as unsuccessful obstruction of bleeding and the formation of thick blood needed an application of the thrombolytic agent to that particular site in veins, medical involvement is indispensable for directing thrombolytic mediator into veins [2]. Streptokinase is also among those mediators comprising 414 amino acid residues and $47 \mathrm{kDa}$ of molecular weight [3]. In contrast with the supplementary plasminogen activators of other varieties, streptokinase holds a great affinity for circulatory plasminogen and has an extended period of half-life [4]. Hence streptokinase is principally and commonly utilized plasminogen activator in the deprived health care organization of the world due to its cheap price [5]. Streptokinase, a fibrinolytic enzyme, is obtained from many foods for achieving physiochemical properties. Other than these, there is a very famous Asian seasoning known as fermented shrimp paste that exhibited strong fibrinolytic activity [6]. These traditional Asian foods bestow these enzymes with a particular activity which is very valuable in thrombolytic therapy. For curing cardiac diseases, these gave an alternative to the costly fibrinolytic enzymes, which are presently used [6]. The Streptococci strains can produce streptokinase but good handling is needed due to the pathogenic activity of streptokinase [7].

Bagasse, the fibrous residues left behind when sugarcane is compressed in the refining factory of sugar to collect juice which in other countries is also recognized by the name bagasse. The word bagasse is originated from the Spanish and French word known as "bagazo" specified for the outer dry layer of olives or grapes taken as waste materials remained after extracting their fillings through compressing. This bagasse contained almost $1-3 \%$ dissolved solids, 47-50\% moisture, and 48-50\% fiber, including sugar, and is mainly utilized for the production of paper [8]. Furthermore, bagasse is composed of about 25\% lignin, 25\% hemicelluloses, and $50 \%$ cellulose. Hence, bagasse presents as an ideal substrate for microbial processes for the manufacturing of value-added products because of its copious availability. From bagasse, efforts have been made to manufacture substrate protein-enriched organic acids, animal feed, amino acids, enzymes and compounds of pharmaceutical importance, etc. [9]. Improved substrate consumption is often attained through a pre-treatment process in the presence of microbes. Similarly, metal ions play an important role in microbial growth and metabolism. Therefore, the use of metal ions is recommended in culture medium for the optimum yields of bacterial products like antibiotics, enzymes, etc. [10, 11]. In this study, we optimized the production of the streptokinase enzyme by a $\beta$-hemolytic Streptococcus equisimilis in a liquid culture medium. The medium contained $4 \%$ bagasse and four metal ions were used at different levels to optimized the production of the streptokinase enzyme. Streptokinase extracted from culture media of streptococci strain was later purified.

\section{Material and Methods}

\section{Microbial strain}

The elected microorganism Streptococcus equisimilis (ATCC 12394, Gene Bank accession number CP002215) for the production of streptokinase in submerged fermentation was obtained from the Enzyme Biotechnology Laboratory (EBL), Department of Biochemistry, University of Agriculture, Faisalabad, Pakistan. Using the blood agar medium, $S$. equisimilis growth was recognized and used as a confirmation for streptokinase enzyme [10].

\section{Enzyme production}

The liquid medium used to obtain the highest production of streptokinase was composed of sugarcane bagasse $4 \%$ as a substrate along with glucose $2 \%, \mathrm{KH}_{2} \mathrm{PO}_{4}, 0.04 \% \mathrm{MgSO}_{4} .7 \mathrm{H}_{2} \mathrm{O} 0.04 \%$, $\mathrm{NaHCO}_{3} 0.15 \%$ and $\mathrm{CaCO}_{3} 0.004 \%$ [11]. The pH was adjusted to 7 with $1 \mathrm{M} \mathrm{HCl}$ or $1 \mathrm{M} \mathrm{NaOH}$. Optimization of various metal ions for the optimal production of streptokinase was done separately as described below to acquire the highest production of enzyme. For culturing, one $\mathrm{ml}$ of overnight inoculum of $S$. equisimilis was used and the incubation was sustained at $120 \mathrm{rpm}$ in an orbital shaker having $37^{\circ} \mathrm{C}$ for 24 hours. Streptokinase enzyme was harvested from biomass by filtration and then centrifugation at $10,000 \mathrm{rpm}$ for 20 
minutes at $0^{\circ} \mathrm{C}$. Enzyme was stored at $-20^{\circ} \mathrm{C}$ and supernatant was assayed for enzyme activity [12].

\section{Optimization of metal ions}

We selected four salts as metal ions sources to optimize the production of streptokinase. The relative activity and quantitative estimation of the streptokinase enzyme were approximated as described by other researchers [13,14]. Biuret method was used for the protein estimation and spectrophotometric observation using Bovine serum albumin as standard [15].

\section{Optimization of $\mathrm{KH}_{2} \mathrm{PO}_{4}$}

Effects of five different concentrations of $\mathrm{KH}_{2} \mathrm{PO}_{4}$ $(0.01,0.02,0.03,0.04,0.05,0.06$ and $0.07 \%)$ were evaluated for attaining maximal production of streptokinase enzyme.

\section{Optimization of $\mathrm{MgSO}_{4} .7 \mathrm{H}_{2} \mathrm{O}$}

To determine the maximal streptokinase production, five concentration levels of $\mathrm{MgSO}_{4} .7 \mathrm{H}_{2} \mathrm{O}(0.02,0.04,0.06,0.08$ and $0.10 \%)$ [16].

\section{Optimization of $\mathrm{NaHCO}_{3}$}

For optimal production of streptokinase enzyme, the effect of five different concentrations of $\mathrm{NaHCO}_{3}(0.10,0.15,0.20,0.25,0.30,0.35,0.40$ and $0.45 \%$ ) was deliberated in conjunction with optimal $\mathrm{KH}_{2} \mathrm{PO}_{4}$ and $\mathrm{MgSO}_{4} .7 \mathrm{H}_{2} \mathrm{O}$ concentrations in the fermentation medium of $S$. equisimilis.

\section{Optimization of $\mathrm{CaCO}_{3}$}

Effect of seven different concentrations of $\mathrm{CaCO}_{3}$ $(0.01,0.02,0.03,0.04,0.05,0.06$ and $0.07 \%)$ for the maximum production of streptokinase were used in the liquid state fermentation medium along with the optimum levels of $\mathrm{NaHCO}_{3}, \mathrm{KH}_{2} \mathrm{PO}_{4}$ and $\mathrm{MgSO}_{4} .7 \mathrm{H}_{2} \mathrm{O}$.

\section{Enzyme assay}

Different pre-weighed germ-free microcentrifuge tubes of $500 \mu \mathrm{l}$ were used for pouring venous blood taken from healthy humans after incubation of 60 minutes at $37^{\circ} \mathrm{C}$. Entire removal of serum was done after clot formation and every single tube containing clot was weighed again to find out the weight of clot (weight of clot $=$ weight of clot containing tube - weight of tube alone). Appropriate labeling of tubes was done and different dilutions were administered combined with $200 \mu 1$ streptokinase liquid culture or purified enzyme in each tube. Water along with clot formation in one tube was set as a control group. Each of the tubes was then incubated for 90 minutes at $37^{\circ} \mathrm{C}$ to observe clot lysis. After incubating them all, the obtained liquid was removed to examine the difference in weight as the tubes were weighed again after disruption in the clot. Variation in weight after and before lysis of blood clot was articulated as a percentage of clot breakage. According to Madhuri et al. [16], streptokinase enzyme activity was considered I unit (U) if $0.12 \mathrm{ml}$ enzyme solution completely lysed 1 $\mathrm{ml}$ of human clotted blood. Each assay was replicated three times [17].

\section{Enzyme purification}

Fibrinolytic enzyme was partially separated from liquid culture using the ammonium sulfate precipitation method. For purification, ionexchange chromatography was carried out as DEAE-cellulose column chromatography. The crude enzyme was obtained from streptococci strain $S$. equisimilis showed a specific activity of 19.86 $\mathrm{Umg}^{-1}$. After dialysis, the desalted sample showed increased activity of $387 \mathrm{U} \mathrm{ml}^{-1}$. The substrate used gave the streptokinase-specific activity of $68.17 \mathrm{Umg}^{-1}$ after the chromatography steps. The fibrinolytic enzyme was further purified by gel permeation chromatography using a Sephadex G-150 column based on the molecular difference of size, which has to eliminate. Later, the SDS-PAGE was carried out using $12 \%$ resolving gel, $4 \%$ stacking gel and $25 \mathrm{mM}$ Tris buffer ( $\mathrm{pH}$ 8.3) having 0.1\% SDS. Later for staining, Coomassie brilliant blue (R-250) was used to determine the molecular weight of the purified enzyme as described previously [18].

\section{Results}

\section{Effect of $\mathrm{KH}_{2} \mathrm{PO}_{4}$}

The effect of different concentrations of $\mathrm{KH}_{2} \mathrm{PO}_{4}$ was observed on the production of streptokinase. The results manifested that the maximum streptokinase production (335.2 $\left.\mathrm{Uml}^{-1}\right)$ was obtained from $S$. equisimilis by using $0.04 \%$ concentration of $\mathrm{KH}_{2} \mathrm{PO}_{4}$ along with sugarcane bagasse $(4 \%)$ as substrate in liquid culture after 24 hours at $37^{\circ} \mathrm{C}$.

\section{Effect of $\mathrm{MgSO}_{4} .7 \mathrm{H}_{2} \mathrm{O}$}

The effect of different concentrations of $\mathrm{MgSO}_{4} .7 \mathrm{H}_{2} \mathrm{O}$ was observed on the production of 


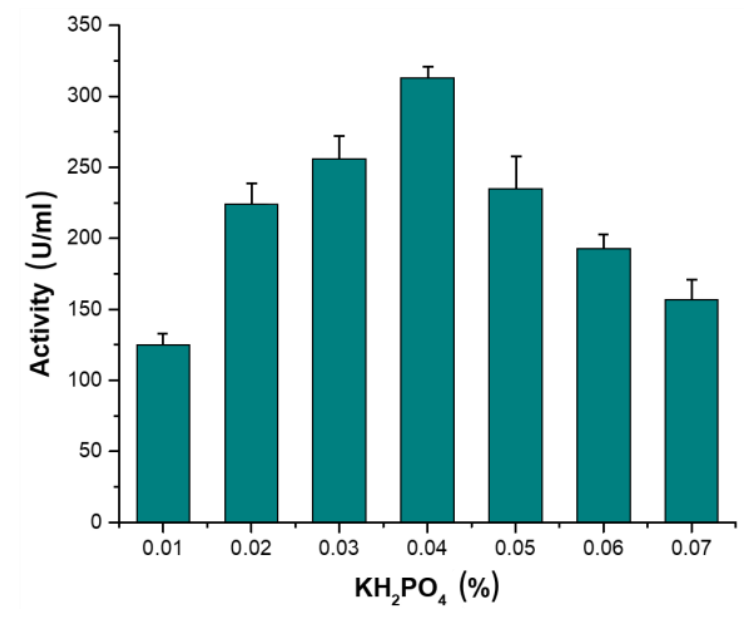

Fig. 1 Streptokinase production from Streptococcus equisimilis at different $\mathrm{KH}_{2} \mathrm{PO}_{4}$ concentrations by using sugarcane bagasse as a substrate.

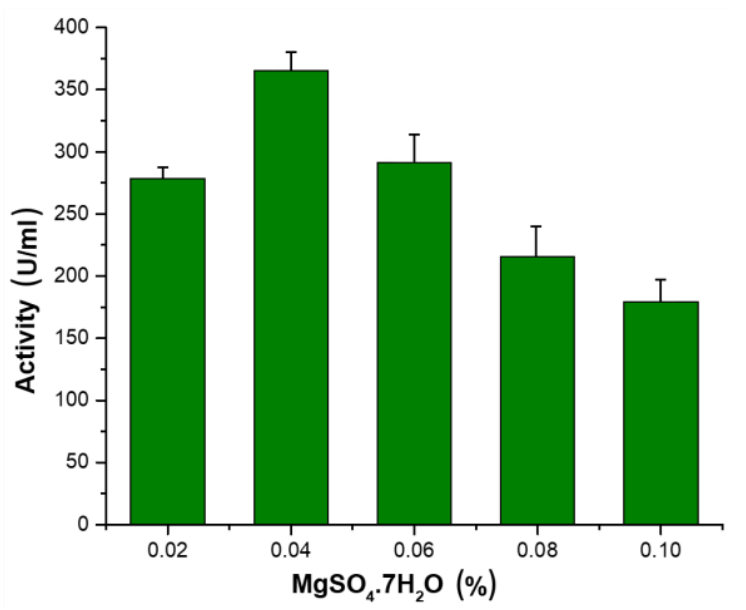

Fig. 2 Streptokinase production from Streptococcus equisimilis at different $\mathrm{MgSO}_{4} .7 \mathrm{H}_{2} \mathrm{O}$ concentrations by using sugarcane bagasse as a substrate.

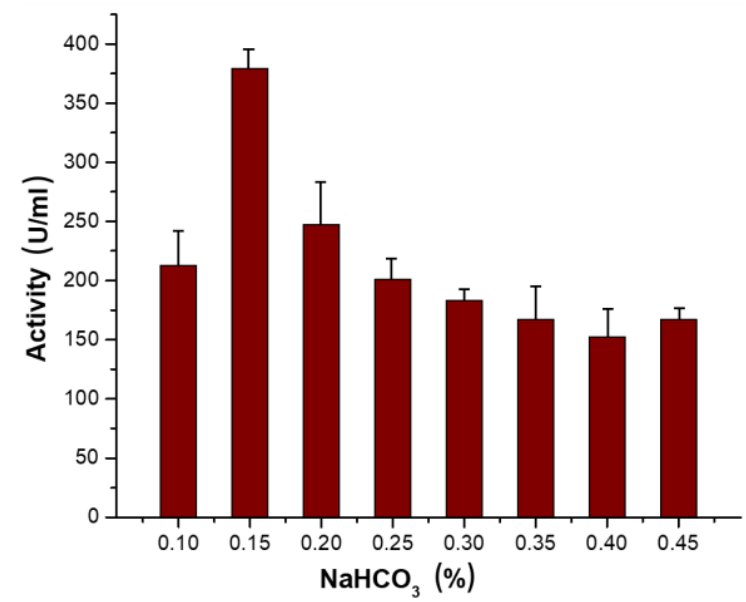

Fig. 3 Streptokinase production from Streptococcus equisimilis at different $\mathrm{NaHCO}_{3}$ concentrations by using sugarcane bagasse as a substrate. streptokinase. In the liquid culture medium containing optimum concentrations of sugarcane bagasse substrate $(4 \%)$ and $\mathrm{KH}_{2} \mathrm{PO}_{4}(0.04 \%)$ for 24 hours at $37^{\circ} \mathrm{C}, \quad 0.04 \%$ concentration of $\mathrm{MgSO}_{4} .7 \mathrm{H}_{2} \mathrm{O}$ was selected for maximal streptokinase production $\left(342.4 \mathrm{Uml}^{-1}\right)$ from $S$. equisimilis.

\section{Effect of $\mathrm{NaHCO}_{3}$}

The effect of different concentrations of $\mathrm{NaHCO}_{3}$ was determined on the production of streptokinase. In the liquid culture medium containing optimum concentrations of sugarcane bagasse substrate (4\%), $\mathrm{KH}_{2} \mathrm{PO}_{4}(0.04 \%)$ and $\mathrm{MgSO}_{4} .7 \mathrm{H}_{2} \mathrm{O}(0.04 \%)$ for 24 hours at $37^{\circ} \mathrm{C}, 0.15 \%$ concentration of $\mathrm{NaHCO}_{3}$ was selected for maximal streptokinase production (361.4 $\mathrm{Uml}^{-1}$ ) from $S$. equisimilis.

\section{Effect of $\mathrm{CaCO}_{3}$}

The effect of different concentrations of $\mathrm{MgSO}_{4} .7 \mathrm{H}_{2} \mathrm{O}$ was observed on the production of streptokinase. In the liquid culture medium containing optimum concentrations of sugarcane bagasse substrate (4\%), $\quad \mathrm{KH}_{2} \mathrm{PO}_{4} \quad(0.04 \%)$, $\mathrm{MgSO}_{4} .7 \mathrm{H}_{2} \mathrm{O}(0.04 \%)$ and $\mathrm{NaHCO}_{3}(0.15 \%)$ for 24 hours at $37^{\circ} \mathrm{C}, 0.04 \%$ concentration of $\mathrm{CaCO}_{3}$ was selected for maximal streptokinase production (342.4 $\mathrm{Uml}^{-1}$ ) from S. equisimilis.

\section{SDS-PAGE analysis}

SDS PAGE was done to detect the molecular weight of enzyme streptokinase from $S$. equisimilis by employing $12 \%$ resolving gel and $4 \%$ stacking gel. It was accomplished that the molecular weight of obtained purified protein band of $47 \mathrm{kDa}$ was in approximation to streptokinase enzyme.

\section{Discussion}

The Streptococci species are among the principal life forms reported for utilization of industrial production of streptokinase. The streptokinase enzyme has not only clinical importance but is also a very cost-effective plasminogen activator [2]. The enzyme streptokinase is a proteolytic enzyme and it is capable to dissolve fibrin production and constancy [1]. Most of the diseases related to heart and myocardial infarction are caused due to thrombosis which is a consequence of the amassing of fibrin in the blood vessels [8]. Microbial fibrinolytic enzymes used in the thrombolytic activity are currently attaining greater interest than classic thrombolytic agents having high cost 


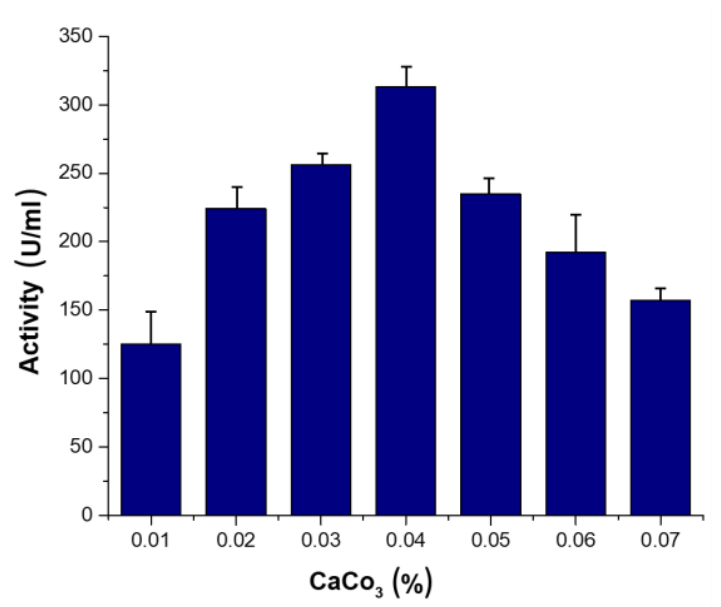

Fig. 4 Streptokinase production from Streptococcus equisimilis at different $\mathrm{CaCO}_{3}$ concentrations by using sugarcane bagasse as a substrate.

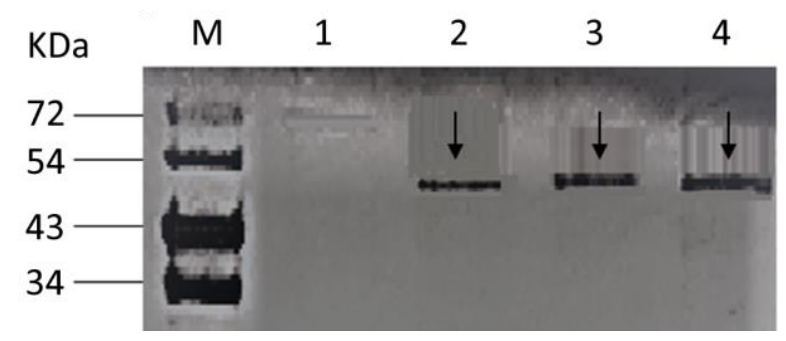

Fig. 5 SDS-PAGE analysis. Lane M, molecular weight markers (kDa); Lane 1, control and Lane 2-4 exhibit three replicates of $47 \mathrm{kDa}$ streptokinase enzyme.

together with later on objectionable side effects [2]. Thrombolytic agents for therapy are used to activate the fibrinolytic system by converting the inactive plasminogen, proenzyme into the active enzyme plasmin, which degrades the fibrin target. There is a vast variety of microorganisms (Staphylococcus, Bacillus, Escherichia coli, and Pseudomonas) used for the production of fibrinolytic enzyme streptokinase [19]. However, bacterial species of Streptococci, especially $S$. equisimilis is considered an excellent source of streptokinase enzyme [20.21].

Enzyme assay of streptokinase relies on its ability to activate plasminogen to plasmin, which in turn, hydrolyzes an indicator substrate, and the extent of hydrolysis over a given period is related to the concentration of streptokinase. According to Devi et al. [22] and Pratap et al. [23], substrates for plasmin may include the casein, fibrin clot, other proteins, and various synthetic esters, which have been utilized for the sensitive detection of the enzyme activity. Maximum clot lysis of about $67 \%$ was observed, which is very promising for streptokinase production. The sugarcane bagasse showed the highest enzyme production as substrate in a previous study so it was used for this study [11]. The optimum $\mathrm{pH}$ of streptokinase was 7 and $47 \mathrm{kDa}$ molecular weight was attained. These findings showed us that waste agro-industrial wastes can be considered as one of the abundant sources of fibrinolytic enzymes. Work on microorganisms producing fibrinolytic enzymes from a variety of traditional Asian fermented foods have also been reported and these organisms were mostly of the genus Bacillus [24]. S. equisimilis showed maximum production of thrombolytic (fibrinolytic) enzyme streptokinase by the use of agro-waste sugarcane bagasse. Therefore, fibrinolytic enzyme obtained from sugarcane bagasse exhibited $84.75 \mathrm{U} \mathrm{mg}^{-1}$ specific activity along with 4.26 times fold purification and $74.5 \%$ recovery. Later, four metal ions were chosen to optimize their concentration and to further improve streptokinase enzyme production in the liquid culture medium. Our results showed that maximal streptokinase production was found at $0.04 \%$

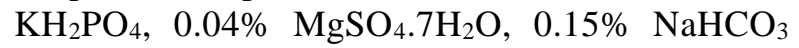
and $0.04 \% \mathrm{CaCO}_{3}$. Stephani et al. [13] also reported optimal yield of streptokinase enzyme by using an increased amount of metal ions from bacterial strains. Similarly, Prasad et al. [14] used $0.01 \% \mathrm{MgSO}_{4} .7 \mathrm{H}_{2} \mathrm{O}$ for optimal production of streptokinase. We found an improved yield of streptokinase in this study with $0.15 \%$ level of $\mathrm{NaHCO}_{3}$ which is in strong association with the work done by other researchers [25-28]. Madhuri et al. [16] reported that when the growth medium contains $0.004 \% \mathrm{CaCO}_{3}$, it gave hyper-production of streptokinase using bacterial strain. The $\mathrm{CaCO}_{3}$ concentration level of $0.005 \%$ was also employed under similar conditions to enhance the yield of streptokinase by other researchers [11]. These findings correlate with the present research work for the maximal production of streptokinase. The SDS-PAGE was used to determine the molecular weight of purified streptokinase, which was found to be $47 \mathrm{KDa}$. This finding is in accordance with the findings of Felsia et al. [8] who also isolated 47 KDa streptokinase enzyme from the liquid culture of another bacterial strain, S. pyogenes.

\section{Conclusions}

The thrombolytic agents have numeral benefits in the world of presently used drugs. The Streptococci species have shown great potential for the production of thrombolytic enzymes in culture 
medium. In this study, we optimized the liquid culture medium for the production of the thrombolytic enzyme "streptokinase" by a bacterium S. equisimilis. Our results showed that sugarcane bagasse appeared to be a good substrate and the production of enzyme was further improved by step-wise optimization of four metal ions $\left(\mathrm{KH}_{2} \mathrm{PO}_{4}, \quad \mathrm{MgSO}_{4} .7 \mathrm{H}_{2} \mathrm{O}, \mathrm{CaCO}_{3}\right.$ and $\mathrm{NaHCO}_{3}$ ). The above-given results suggest that optimization of environmental and nutritional conditions significantly improved thrombolytic enzyme production in liquid culture. Later, the enzyme was purified using more than one purification step and its molecular weight was determined. So as per future aspects, in clinical practice, these findings can be applied due to their cost-effectiveness and cheap rates for the treatment of thrombosis.

\section{Conflict of interest}

The authors declare no conflict of interest.

\section{References}

[1] Chaudhary A, Bhusare DB, Ahmed K, Vayewahare $\mathrm{R}$, Biyani A. Analysis of streptokinase as a fibrinolytic agent in patients with elevation myocardial infarction. Glob J Res Analy 2017; 6(7):1-3.

[2] Collen D, Stump DC, Gold HK. Thrombolytic therapy. Annu Rev Med 1988; 39:405-423.

[3] Malke H, Ferretti JJ. Streptokinase: cloning, expression, and excretion by Escherichia coli. Proc Nat Acad Sci USA 198481:3557-3561.

[4] Banerjee A, Chisti Y, Banerjee UC. Streptokinase, a clinically useful thrombolytic agent. Biotechnol Adv 2004; 22:287-307.

[5] Patil R. Screening of potential streptokinase producing Streptococcus strain. Int J Biol Res 2004; 3:213-216.

[6] Pandey A, Soccol CR, Nigam P, Soccol VT. Biotechnological potential of agro-industrial residue. I: sugarcane bagasse. Bioresour Technol 2000; 74:6980.

[7] Abd-Rabboh HSM, Nevins SA, Nedime A, Meyerhoff ME. Electrochemical assay of protease activities based on polycation/ polyanion complex as substrate and polyion sensitive membrane electrode detection. Biosens Bioelectron 2003; 18: 229-236.

[8] Felsia FX, Kummar RV, Kalpana S. Production and partial purification of streptokinase from Streptocccous pyogenes. J Biochem Technol 2011; 3:289-291.

[9] Raza W, Yang W, Faheem M, Yousaf S. Optimization and effect of $\mathrm{Zn}^{2+}, \mathrm{Mn}^{2+}$ and $\mathrm{Ni}^{2+}$ on poly- $\beta$-hydroxybutyrate (PHB) synthesis by Bacillus subtilis ATCC 6633. Sci Lett 2013; 1(1):5-8.
[10] Raza W, Yang X, Wu H, Huang Q, Xu Y, Shen Q. 2010. Evaluation of metal ions $\left(\mathrm{Zn}^{2+}\right.$, $\mathrm{Fe}^{3+}$ and $\mathrm{Mg}^{2+}$ ) effect on the production of fusaricidin type antifungal compounds by Paenibacillus polymyxa SQR-21. Bioresour Technol 2010; 101:9264-9271.

[11] Zia MA, Faisal R, Abbas RZ, Faran G, Saleemi MK, Khan JA. Comparison of streptokinase activity from Streptococcus mutans using different substrates. Pak Vet J 2013; 33(1):77-79.

[12] Faran G, Zia MA, Shahid M, Sajid A. Improved streptokinase production; UV irradiation of Streptococcus equisimilis. Prof Med J 2015; 22:656663.

[13] Stephani L, Tjandrawinata RR, Afifah DN, Lim Y, Ismaya WT, Suhartono MT. Food origin fibrinolytic enzyme with multiple actions. HAYATI J Biosci 2017; 24:124-130.

[14] Prasad S, Kashyap RS, Deopujari JY, Purohit HJ, Taori GM, Daginawala HF. Development of an in vitro model to study clot lysis activity of thrombolytic drugs. 2006; Throm J 4:14.

[15] Zaia DAM, Marques FR, Zaia CTBV. Spectrophotometric determination of total proteins in blood plasma: a comparative study among dyebinding methods. Braz Arch Biol Technol 2005; 48(3):385-388

[16] Madhuri DH, Manohar M, Singh NA, Mohanasrinivasan V, Devi CS. Studies on isolation, screening, and strain improvement of Streptokinase producing $\beta$-hemolytic Streptococci. 2011; World J of Sci Technol 1: 7-11.

[17] Shilpi B, Angayarkanni J, Souray B, Arijit D, Palaniswamy M. Isolation, screening, and characterization of beta-hemolytic Streptococci with potential of streptokinase production. Int $\mathrm{J}$ Biol Sci 2013; 2(4):63- 66.

[18] Negar S, Shekari P, Bandehpour M, Sharifnia Z, Parivar K, Kazemi B. Production of mutant streptokinase recombinant protein. Iran J Clin Infect Dis 2008; 3(4):179-183.

[19] Ghaffar A, Ahmed B, Munir B, Faisal R, Mahmood Z. Production and characterization of streptokinase enzyme by using Streptococcus mutans strain in liquid state fermentation through corn steep liquor (CSL) substrate. Biochem Physiol 2015; 4:178.

[20] Balaraman K, Prabakaran G. Production and purification of a fibrinolytic enzyme (thrombinase) from Bacillus sphaericus. Indian J Med 2007; 126(5):459-464.

[21] Babashamsi M, Razavian MH, Nejadmoghaddam MR. Production and purification of streptokinase by protected affinity chromatography. Avicenna J Med Biotechnol 2009; 1(1):47-51.

[22] Devi CS, Mohanasrinivasan V, Vaishnavi B, Selvarajan E, Naine SJ. Optimization studies for enhanced production of streptokinase by $S$. equisimilis UVM6. J Pure Appl Microbiol 2013; 7:2337-2341.

[23] Pratap J, Rajamohan G, Dikshit KL. Characteristics of glycosylated streptokinase secreted from Pichia pastoris: enhanced resistance of SK to proteolysis by 
glycosylation. Appl Microbiol Biotechnol 2000; 53:469-475.

[24] Mundada LV, Prorok M, DeFord ME, Figuera M, Castellino FJ, Fay WP. Structure-function analysis of the streptokinase amino terminus (residues 1-59). J Biol Chem 2003; 278:24421-24427.

[25] Mahmoudi S, Abtahi H, Bahador A, Mosayebi G, Salmanian AH, Teymuri M. Optimizing of nutrients for high level expression of recombinant streptokinase using pET32a expression system. J Clin Med 2012; 7(3):241.
[26] Patil R. Screening of potential streptokinase producing Streptococcus strain. Int J Biol Res 2018; 3:213-216.

[27] Naeem M, Sadia B, Awan FS, Zia MA. Enhanced production of streptokinase by $\mathrm{UV}$-and ethidium bromide-treated Streptococcus equisimilis mutant. 2018; Pak J Zool 50(2):655-661.

[28] Baewald G, Mayer G, Heikel R, Volzke KD, Roehlig R, Decker KL. Fermentative production of Streptococcus metabolites, especially streptokinase. German patent; 1975, DD 111096. 